\title{
Like "Monkeys at the Zoo": Politics and the Performance of Disability at the Iowa Soldiers' Home, 1887-1910
}

\author{
BRIAN EDWARD DONOVAN
}

WHEN THE IOWA SOLDIERS' HOME opened its doors in December 1887, the Civil War had been over for 22 years. Veterans of the conflict were entering middle age; for most, their army service was rapidly taking on the glow of nostalgia. ${ }^{1}$ In most midwestern towns, the local post of the Grand Army of the Republic (GAR) and its auxiliaries in the Women's Relief Corps (WRC) acted as a kind of community social club, organizing Fourth of July parades, ice cream socials, and Decoration Day commemorations. Uninjured veterans had transitioned into civilian careers more or less smoothly after demobilization, and by the late 1880s an ever more generous pension system provided a moderate (if far from princely) living for honorably scarred old soldiers. For those men too damaged by war to

1. The typical Civil War enlistee was about 23 years old, so the average veteran in 1887 would have been about 45 . For this and other statistics, see especially Maris Vinovskis, Toward a Social History of the American Civil War: Exploratory Essays (New York, 1990). See also James M. McPherson, Battle Cry of Freedom: The Civil War Era (New York, 1988). On veterans' nostalgia in the broader context of Gilded Age culture, see especially David W. Blight, Race and Reunion: The Civil War in American Memory (Cambridge, MA, 2001).

The research for this article was supported by a grant from the State Historical Society of Iowa.

THE ANNALS OF IOWA 71 (Fall 2012). (C) The State Historical Society of Iowa, 2012. 
work, or bereft of the family or communal support necessary for independent living, the National Home for Disabled Volunteer Soldiers (NHDVS) provided asylum care at taxpayer expense for those who qualified. ${ }^{2}$

This last provision was crucial. By 1885, the federal government had already spent nearly $\$ 180$ million on pension arrears, but it was still not enough. ${ }^{3}$ The ironclad logic of bureaucracies dictates that even the most progressive social assistance scheme will not reach all the needy; thanks to the requirement that disabilities be provably service-related, many suffering Union veterans were unable to tap into federal assistance programs. The sight of old soldiers in state poorhouses-or, worse, begging in the streets-was increasingly common in northern states during the Gilded Age. "That all soldiers have earned all that their friends ask for them there can be no doubt," the Oskaloosa Herald thundered in a typical editorial. "Will we go on record, like those of the past who suffered their benefactors after having given their fortune and their strength to their nation in her hour of peril, to die in the poorhouse or be dependent upon the charities of society?"

The problem was largely political. Starting in 1885, pension payments to disabled Union soldiers and their dependents was the single largest expenditure in the federal budget behind service on the national debt. That would continue until 1897, by which time nearly a million men were on the rolls; by 1907,

2. For GAR activities, see especially Stuart Charles McConnell, Glorious Contentment: The Grand Army of the Republic, 1865-1900 (Chapel Hill, NC, 1992). For pensions, the standard reference remains William Henry Glasson and David Kinley, Federal Military Pensions in the United States (New York, 1918). See also Larry M. Logue and Peter David Blanck, Race, Ethnicity, and Disability: Veterans and Benefits in Post-Civil War America (New York, 2010); and Peter David Blanck, "Before Disability Civil Rights: Civil War Pensions and the Politics of Disability in America," Alabama Law Review 52 (2000), 1-50. On the NHDVS, see Patrick J. Kelly, Creating a National Home: Building the Veterans' Welfare State, 1860-1900 (Cambridge, MA, 1997).

3. McConnell, Glorious Contentment, 147; Kelly, Creating a National Home, 5.

4. See, for instance, McConnell, Glorious Contentment, 142. An 1885 study by the Pennsylvania GAR found between 300 and 400 men in the Commonwealth's poorhouses. The presence of old soldiers in Iowa poorhouses is a nearly constant refrain in Republican Party newspapers throughout the period. See, for example, Oskaloosa Herald, 6/6/1887. 
this largesse had totaled more than $\$ 1$ billion. ${ }^{5}$ In addition, the NHDVS had six branches by 1887, and plans were in the works for two more (in Marion, Indiana, and Santa Monica, California, both opened in 1888). Forcing through more federal-level assistance would be problematic, to say the least, in light of these enormous sums, especially with Democrat Grover Cleveland in the White House. The GAR's arrogance did not help matters: "The GAR own this country by the rights of a conqueror," money-hungry New York comrades asserted in 1886. It is hardly surprising that not long afterwards Cleveland vetoed the Grand Army's proposed "service pension". ${ }^{6}$ Clearly a statelevel solution had to be found for the problem of desperately needy men without clear proof of service-related disability.

Iowa's solution was the Iowa Soldiers' Home (ISH), which dovetailed neatly with the Iowa GAR's political agenda. A politically crucial state throughout the 1880s and '90s, Iowa had been strongly Republican during the war years. Beginning in 1878, however, declining farm prices and populist agitation challenged GOP dominance of the state. That year, the Greenback-Labor Party sent two Iowans to the 46th Congress. Two years later, one of those congressmen, former Union general James B. Weaver, would head the Greenback presidential ticket and capture just over 3 percent of the national popular vote. With much Greenback support coming from the Midwest, the "soldier vote" was crucial for keeping Iowa within the Republican fold. By pushing through a state soldiers' home, the Iowa GAR could aid its destitute comrades while shoring up veteran support for the state Republican Party. The ISH was given an initial appropriation of $\$ 100,000-\$ 75,000$ for construction of the physical plant and a $\$ 25,000$ "support fund" from which to pay officers, purchase supplies, and provide for residents (called "inmates") at \$10 per man per month. ${ }^{7}$

5. Kelly, Creating a National Home, 153.

6. McConnell, Glorious Contentment, 156.

7. For more detailed analyses of Iowa politics in this period, see especially Richard J. Jensen, The Winning of the Midwest: Social and Political Conflict, 18881896 (Chicago, 1971); Paul Kleppner, The Cross of Culture: A Social Analysis of Midwestern Politics, 1850-1900, 2nd ed. (New York, 1970); and Ballard Campbell, Representative Democracy: Public Policy and Midwestern Legislatures in the 
OPEN TO ALL honorably discharged veterans of the Union army and navy, the ISH was tasked with providing living space and medical care to those veterans "unable to earn a $1 / 4$ living at manual labor." Those soldiers drawing pensions would contribute all but $\$ 6$ of their checks to the home's maintenance fund; that, the commissioners hoped, would make the ISH self-sufficient. It was not to be.

Although the home "opened with [just] seven inmates" in December 1887, Commandant Milo Smith soon found himself swamped with more applications than his facilities could handle. By January 1888 there were 66 old soldiers in the home, with 30 additional applicants approved for admission and 90 more applications issued and being prepared for admission. "The present indications are that the Home will be filled to its full capacity during the year 1888," Smith concluded. The commissioners concurred and requested an appropriation of $\$ 2,750$ "for 200 more inmates than now provided for." ${ }^{8}$

As the nation's veteran population aged, the number of men in the ISH grew dramatically, rising to 360 "crippled and dependent" old soldiers in 1890 and 585 ("including twelve women") by 1895 . Overcrowding was endemic. As the 1895 report reminded the state legislature, the ISH was designed to house "no more than 300 inmates." Moreover, although an 1889 act of Congress supplemented the home's budget by paying $\$ 100$ per inmate to each state soldiers' home, the ISH, like all state institutions (and, indeed, the NHDVS) remained overcrowded and underfunded. ${ }^{9}$

Late Nineteenth Century (Cambridge, MA, 1980). On the Greenback Party, see especially Mark A. Lause, The Civil War's Last Campaign: James B. Weaver, the Greenback-Labor Party and the Politics of Race and Section (Lanham, MD, 2001). See also Thomas Burnell Colbert, "James Baird Weaver and the Election of 1878" (M.A. thesis, University of Iowa, 1975). For a detailed analysis of the Iowa GAR in state politics, see Charles Thurman Mindling, "The Grand Army of the Republic in Iowa Society and Politics" (M.A. thesis, University of Iowa, 1949). Statistics come from Report of the Board of Commissioners of the Iowa Soldiers' Home to the Twenty-Second General Assembly (Des Moines, 1888), 3-7 (hereafter cited as Commissioners Report, [year].

8. Commissioners Report, 1888, 8-9.

9. Commissioners Report, 1895, 3. On the 1889 act, see Commissioners Report, $1889,14-15$. For the NHDVS, see especially Kelly, Creating a National Home. 


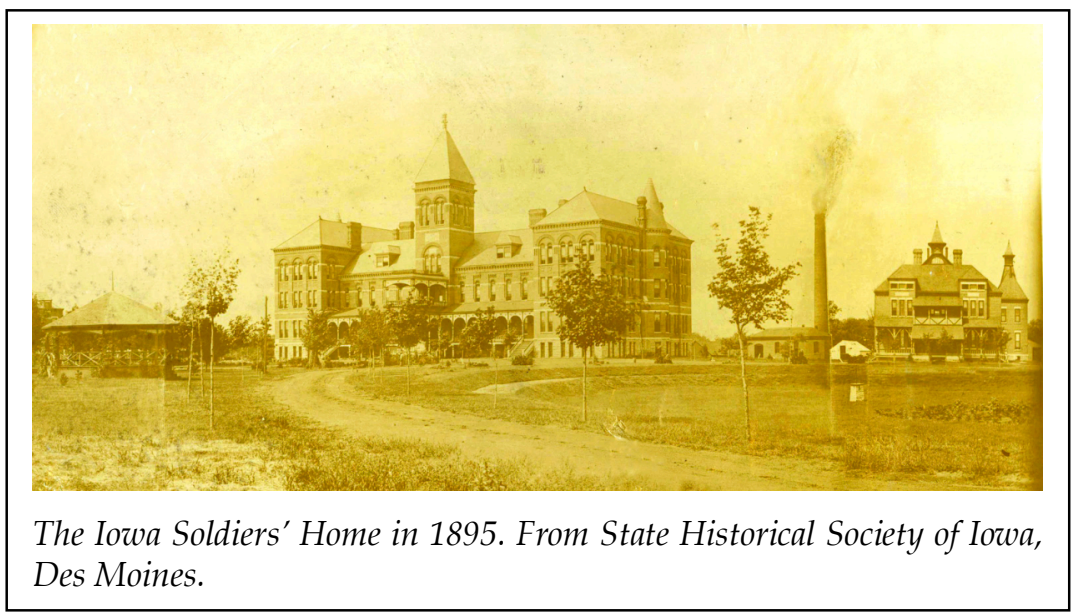

As a piece of political theater, though, the establishment of the ISH was quite effective. Cities lobbied the state for the privilege of hosting the home, and the legislature made a show of consulting the GAR for its input; a special senate commission visited 19 possible locations and compiled a "voluminous report . . . mentioning the desirable features of each."10 Marshalltown offered the most attractive package. Thanks to its generous donation of 128 acres, a free extension of the city's water mains (and free pumping for five years), a rail link, and lowcost gas hookups, that city was chosen for the honor. The ISH opened its doors with great fanfare in December $1887 .{ }^{11}$

Maintaining the home, however, soon became an ongoing public relations headache. Unlike the state's insane asylums, prisons, poorhouses, and vocational schools for the blind, deaf, and dumb, the ISH was not designed to rehabilitate unfortunates or to exclude undesirables from society. Like its federal counterpart, the NHDVS, the Iowa home was, fundamentally, a temporary refuge for transient veterans and a warehouse for the chronically ill. The grateful citizens of Iowa would not allow their ailing defenders to languish in poorhouses, the GAR insisted. But as Henry Bellows, the wartime chairman of the U.S. Sanitary Commission, argued as early as 1863, institutional

10. Alton Weekly Democrat, 4/3/1886; Cedar Rapids Evening Gazette, 4/4/1886.

11. Commissioners Report, 1888, 5. 
charity on this scale "would inevitably degrade these men, corrupt their character, and sap their will, forever undermining their manhood and locking them into a state of perpetual dependence." ${ }^{12}$ Such an insult to a crucial voting bloc was unacceptable. What the ISH provided, then, must actually be charity without seeming so.

THE ONLY SOLUTION, politically and culturally, was to invoke what sociologist T. H. Marshall would come to call "martial citizenship," the informal but very influential set of privileges veterans and others can claim based on their defense of the state. ${ }^{13}$ Disabled veterans requiring institutional care would be classed with the "deserving poor" - the only fit objects for Gilded Age charity-but in return, they would perform their disability for taxpayers, marching to and fro to the call of the bugle in their Union army uniforms and serving, in the words of one embittered resident of the NHDVS, "as much [of] an exhibition here as monkeys at the Zoo."14 Soldiers' homes like the one at Marshalltown would become tourist attractions, with thousands of residents flocking there annually on national holidays (usually aided by special rates offered by local railways) to see the old soldiers. ${ }^{15}$ With these exhibitions, the state (and, of course, the Republican Party) displayed its munificence, while the citizens had the opportunity to confirm that they were getting their money's worth. The home's officers thus found themselves acting as both administrators and camp commandants, publicly enforcing military discipline on old, feeble men.

The uniformed, disciplinary aspect was crucial, for it was often difficult to tell if residents were disabled. Gilded Age Americans associated the Civil War with grievous, visible wounds, especially amputations. The official seal of the NHDVS, for instance, showed Columbia offering succor to an old soldier

12. Quoted in Kelly, Creating a National Home, 23.

13. T. H. Marshall, Class, Citizenship, and Social Development: Essays (Westport, CT, 1973). See also idem, "Social Citizenship and the Defense of Welfare Provision," in Jeremy Waldron, Liberal Rights: Collected Papers 1981-1991 (New York, 1993).

14. Quoted in Kelly, Creating a National Home, 187.

15. See ibid., 183-200. 


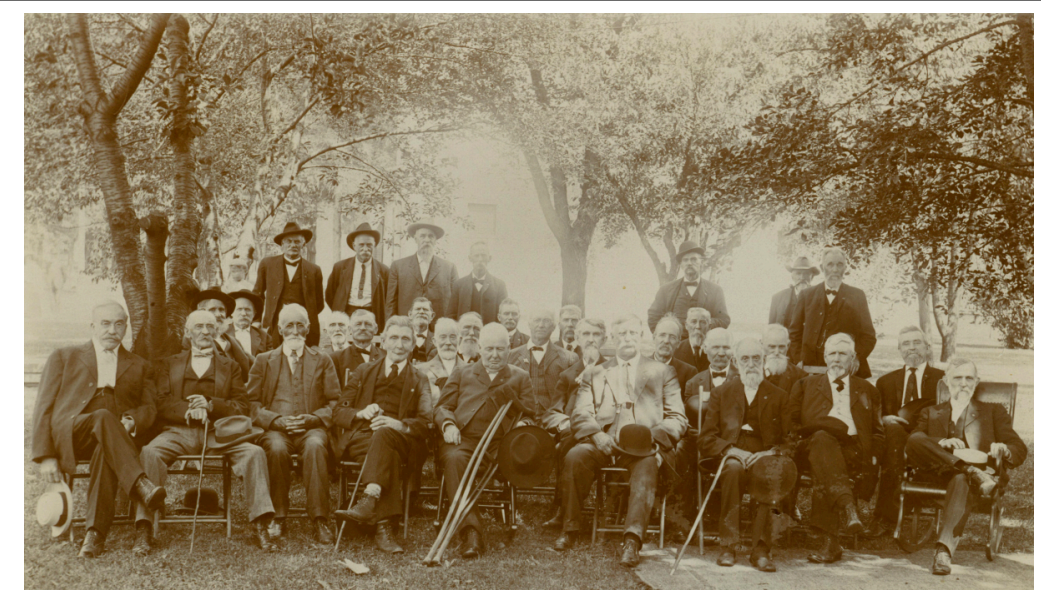

Members of GAR Post 116 in Indianola pose for a photo in 1908. Note that an amputee was placed front and center in the photo. Photo from State Historical Society of Iowa, Des Moines.

missing his right leg. ${ }^{16}$ Moreover, visibly wounded men often played up their missing limbs, especially on the campaign trail. Amputee veterans typically pinned up their clothing, especially in photographs, while disabled politicians like Daniel Sickles and Lucius Fairchild made a claim to voters' special consideration by virtue of their loss. With these associations in mind, visitors to the nation's soldiers' homes expected missing limbs. ${ }^{17}$

Most Civil War casualties, however, were not amputees. Of the 2.2 million men who passed through the Union army, only 281,881 men, or 1.4 percent, were visibly wounded, and slightly

16. Ibid., 128.

17. See especially Laurann Figg and Jane Farrell-Beck, "Amputation in the Civil War: Physical and Social Dimensions," Journal of the History of Medical and Allied Sciences 48 (1993), 454-75. Figg and Farrell-Beck carefully analyzed a broad sample of photographs of disabled veterans to come to these conclusions. Against this notion of proud amputees, however, see Lisa Herschbach, "Prosthetic Reconstructions: Making the Industry, Re-Making the Body, Modelling the Nation," History Workshop Journal 44 (1997), 23-57; and Erin O'Connor, " 'Fractions of Men': Engendering Amputation in Victorian Culture," Comparative Studies in Society and History 39 (1997), 744-47. Frances Clarke, in her study of Civil War injuries, addresses these two interpretations of Civil War amputations. See Frances Clarke, “'Honorable Scars': Northern Amputees and the Meaning of Civil War Injuries," in Paul A. Cimbala and Randall M. Miller, Union Soldiers and the Northern Home Front: Wartime Experiences, Postwar Adjustments (New York, 2002), 364-65. 
fewer than 30,000 were missing body parts. ${ }^{18}$ Even then, the damage was often not visibly dramatic, as most Civil War amputations were of fingers or a hand. ${ }^{19}$ Instead, disease was the real scourge of both armies, carrying off 224,000 Union soldiers outright and more or less permanently affecting the health of hundreds of thousands more. The Union army's medical services treated an astounding seven million cases of disease during the course of the war. Dysentery alone, which could permanently affect a man's health, appeared an astonishing 1.7 million times -nearly one case for every man who had ever worn the blue. ${ }^{20}$ After the war, men who had suffered illness during their service often appeared outwardly normal, even healthy, but were more or less disabled for the purpose of earning a steady living.

Those were the men most in need of aid. At the end of the war, approximately 15 percent of all surviving veterans had been wounded, and thus virtually guaranteed a pension, but by 1875 fewer than half of them had claimed their benefit. Even more surprisingly, only about 9,000 amputees applied for their automatic pension, and even fewer took advantage of the federal government's free artificial limbs. In a study of 100 amputees' pension files, historian Frances Clark found that most men took cash commutations instead. The veteran-oriented newsletter The Soldier's Friend even suggested a lively (though apocryphal) trade in artificial limb vouchers sold at a discount. Clarke attributes these counterintuitive findings to a veterans' culture of masculinity. Whatever the cause, it is clear that most men requiring state aid were not battlefield casualties, but victims of camp disease. ${ }^{21}$

18. Theda Skocpol, "America's First Social Security System: The Expansion of Benefits for Civil War Veterans," Political Science Quarterly 108 (1993), 85-86. See also idem, Protecting Soldiers and Mothers: The Political Origins of Social Policy in the United States (Cambridge, MA, 1992).

19. Robert I. Goler and Michael G. Rhode, "From Individual Trauma to National Policy: Tracking the Uses of Civil War Veteran Medical Records," in Disabled Veterans in History, ed. David A. Gerber (Ann Arbor, MI, 2000), 164.

20. Kelly, Creating a National Home, 15-17.

21. Skocpol, "America's First Social Security System," 95; Clarke, "Honorable Scars"; The Soldier's Friend 2, no. 1 (1866), 2. On manhood, see Clarke, "Honorable Scars," esp. 378-83; and Brian Donovan, "The Harder Heroism of the Hospital: Manhood and Disability in Midwestern Soldiers' Homes, 1884-1910" (Ph.D. diss., University of Iowa, forthcoming). 
Complete statistics unfortunately do not exist for the ISHHome Surgeon Hamilton P. Duffield's reports only listed men who had been in the hospital, and then only by diagnosis-but a sample of admission files reveals an inmate profile roughly similar to that of the NHDVS. At the NHDVS's Northwestern Branch in Milwaukee, which opened in 1868, fewer than half of the applications in the first five years were based on combat injuries, and at the Northern Branch in Togus, Maine, amputees never made up more than 22 percent of the total population. A survey of 612 Northern Branch inmates conducted between 1866 and 1881 confirmed that illness, in peace as in war, felled far more men than bullets: a mere 8 percent of the residents were found to be amputees, and only 38 percent were suffering from the direct effects of wounds. The rest were sick. ${ }^{22}$

ILL INMATES confounded the public's expectations. Worse, their comrades' behavior exacerbated the situation. By the time the ISH opened in 1887, the country had more than 20 years' experience with institutional assistance to ex-soldiers. The results were decidedly mixed. Almost every debarkation point in the Union had had its municipal "soldiers' rest," where men returning from the front could get a meal and a bed. Those institutions quickly grew into hospitals for ill or wounded transients, and many Union soldiers expressed their gratitude for the care received there. However, as General Benjamin Butler, the first commandant of the NHDVS, was forced to admit to Congress in 1868, the urban settings of these soldiers' rests provided "temptations to vice, of which intemperateness and unchasteness are most common; and we find in our hospitals many men sorely afflicted with diseases arising from these causes additional to the wounds and disabilities received in the line of duty." The next year he admitted that local soldiers' homes were "little more than places for [a soldier] to sleep in at night,

22. James Marten, "Exempt from the Ordinary Rules of Life: Researching Postwar Adjustment Problems of Union Veterans," Civil War History 47 (2001), 62; Kelly, Creating a National Home, 128-29, 73. I am grateful to the staff of the Iowa Veterans' Home at Marshalltown, Iowa, for their generous assistance in obtaining a sample of veteran records. Special thanks are due to Roxy West, archivist, and Commandant David G. Worley. 
and to get his meals in when he chose to come to them, while he himself wandered around the cities begging, if doing no worse, | during the day." 23

As the board of managers of the NHDVS rather delicately put it in 1875, a "large number of not the most deserving class of soldiers were among the earliest to claim support," and a great many of those earliest claimants "had never done much service." They "had never been any special value as soldiers," and they had failed to develop "the habits of industry or even the will to earn a living themselves [and were] quite willing to be supported by the Government without labor." ${ }^{24}$ By war's end, then, men without visible wounds were often assumed to be drunks, satyrs, loafers, or some combination of all three.

The experience of the NHDVS compounded the problem. By 1887, the public perception of soldiers' homes as sinks of iniquity was well advanced, thanks largely to the behavior of residents at the two nearest branches. "The sight of NHDVS residents collapsed after a drinking spree was common in every town located near a branch of the network," Patrick Kelly notes; the Central Branch at Dayton, Ohio, alone was surrounded by " 25 or 26 " saloons (many of which also functioned as brothels). The inmates confined there were "constant sufferers" from the debilitating effects of their Civil War service, the National Tribune argued in August 1884, and therefore it was "not surprising ... that some of them have sought the solace of the intoxicating cup, and have fallen victims to its destroying influence." ${ }^{25}$ That the National Tribune, the GAR's national newspaper of record, was forced to make such an argument speaks to the perceived decadence of the Dayton Home.

The situation at the Northwestern Branch in Milwaukee, Wisconsin, was actually worse. In 1881 alone, more than 800 infractions out of a total of 1,840 were for drunkenness; in 18871888, alcohol-related infractions topped 3,000. Drink accounted for a whopping 55 percent of all offenses at the Northwestern

23. Quoted in Kelly, Creating a National Home, 105.

24. Annual Reports of the Board of Managers of the National Asylum for Disabled Volunteer Soldiers for 1868, 1869, and 1875, quoted in Kelly, Creating a National Home, 5.

25. Kelly, Creating a National Home, 176-78. 
Branch from 1888 through 1899, with predictable health consequences for the offenders: throughout the 1880s, 14 percent of all diseases and injuries diagnosed among the residents were somehow tied to drinking. To combat this menace, the board of managers opened a Keeley institute on the home's grounds, and the local GAR chapters railed against the use of their name and logo in taverns. The managers were somewhat successful on the home's grounds-by the mid-1890s, more than 400 men had joined the branch's Keeley League-but enterprising tavern-keepers named their gin mills after heroes of the Union army and replaced official GAR paraphernalia with discreet notices that they employed GAR members. ${ }^{26}$

The officers of the ISH hoped that the state's 1885 prohibition law would prevent such scenes in Marshalltown, but they were disappointed. Indeed, an 1887 Supreme Court case bestowed a little notoriety on the city when, after a committee of concerned citizens impounded a shipment of 5,000 barrels of beer passing through from Chicago, the court ruled that the interstate commerce clause superseded Iowa's prohibition law. ${ }^{27}$ In a further blow to the managers' efforts, prohibition was repealed entirely in 1889, thanks in large part to the defection of many GAR men from the Republican Party on that very issue. The GOP would return to power in the next election (indeed, the Democrats would not recapture the statehouse until the 1932 Roosevelt landslide), but prohibition was a dead letter. The ISH could, and did, banish drinking from the grounds, but the officers could do little about the prevalence of alcohol in the community. ${ }^{28}$

That had predictable effects. "It is a curious feature, in connection with public opinion," Commandant John Keatley wrote in his first biennial report to the legislature, "that many persons, on account of the intemperance of a few, are apt to characterize the entire membership of a soldiers' home as a 'lot of drunken

26. James Alan Marten, "Nomads in Blue: Disabled Veterans and Alcohol at the National Home," in Disabled Veterans in History, esp. 279-82.

27. Bowman vs. Chicago and Northwestern Railway Company 125 U.S. 465 (1887). See http: / / caselaw.lp.findlaw.com / cgi-bin/getcase.pl? court $=$ us \&vol= 125\&invol $=465$, last accessed 9/15/2011.

28. Mindling, "The GAR in Iowa Politics," 68; New York Times, 3/21/1888, 4; Bowman vs. Chicago and Northwestern Railway Company. 
bums.'" It was more than "a few," however. In 1893 ISH surgeon G. W. Harris estimated that up to 10 percent of the home's residents were heavy drinkers and could be seen intoxicated "on the streets of Marshalltown" in their uniforms. In Surgeon Harris's opinion, that number was certainly large enough "to taint the reputation of the Home" among the citizens. He fully supported Commandant Keatley's decision to have "a calaboose" built on the home's grounds "to separate persons in a gross state of intoxication, from other well disposed members of the Home, who otherwise, would be ... subjected to the annoyance of their profanity and other misconduct, due to their condition." ${ }^{29}$

Even when sober, though, the behavior of typical ISH residents did little to dispel the notion that soldiers' homes were full of bums. All soldiers' homes, state or federal, served primarily working-class or even homeless veterans. The Iowa legislature's visiting committee, sent to inspect the ISH in its first full year of operation, reported that a "very large proportion of the inmates are homeless, and have no relations in the State, and many report no known relations living." Fifty-five of the first 66 entrants were single, and a "large per cent" of the 120 applications then outstanding came "from parties now in the alms houses of the State, and for those dependent upon the various charitable societies to which they belong for their subsistence." ${ }^{130}$

WORSE YET, by 1887 most veterans nationwide were well aware of the "charitable" nature of soldiers' homes and tended to use them the way other down-at-the-heel men used poor farms, workhouses, and even prisons: as seasonal refuges in tough economic times. As a result, soldiers' homes tended to be more crowded in winter months and at other times when casual labor was scarce. ${ }^{31}$ As it was a veteran's prerogative to request a

29. Commissioners Report, 1893, 18.

30. Report of the Joint Committee of the 22nd General Assembly of the State of Iowa, Appointed to Visit the Iowa Soldiers' Home Located at Marshalltown (Des Moines, 1888), 2 (hereafter cited as Visiting Committee Report). This ratio was even higher than the National Home's 60 percent. See Kelly, Creating a National Home, 133.

31. Kelly, Creating a National Home, 128, 155-59. See also Michael B. Katz, In the Shadow of the Poorhouse: A Social History of Welfare in America, 10th anniversary ed. (New York, 1996). 
discharge at any time, though, many old soldiers, especially pensioners, frequently left the homes to take up seasonal work-or, worse, to go on drinking sprees. ${ }^{32}$ The constant movement of men one step above destitution in and out of the home made the appearance of soldierly discipline even more critical for those who remained.

In general, though, only the sickest men stayed put. Alfred Renshaw, for instance, was an ex-prisoner of war suffering from a suppurating ulcer on his right leg and a "lame back and hip." Submitting to Surgeon Duffield's examination in 1894, Renshaw was found to have an enlarged heart and left kidney, along with an "impaired" right hand. He died at the home. ${ }^{33}$ More typical were men like George Strabow, who left the ISH three times between 1887 and 1899 and was readmitted twice. Although he was blind in both eyes and suffering from a hernia that had gotten him dismissed from the Iowa College for the Blind because he could not "work hard enough and fast enough to make a living," Strabow preferred life on the outside to the stifling regulations of the ISH. He was discharged for the last time on August 25, 1897, at his own request "rather than comply with pension rules." ${ }^{\prime 34}$

This pattern of discharge and readmission was common at the ISH. Former cavalryman Henry Tracy, a farmer in civilian life, entered the ISH in December 1887. Suffering from chronic diarrhea, piles, and "a general breaking down of the system," Tracy nevertheless discharged himself in the summer of 1894, only to return in May 1895. William Stone, a single laborer suffering from rheumatism "contracted at Fort Donelson," was discharged and admitted four times between 1887 and 1893. Noah H. Isenhower, late of the 31st Iowa, was admitted three times between 1887 and 1899, including once after being dropped from the rolls in 1897. He died of pneumonia in the home in 1910. Patrick Neville, whose army service ended in Oc-

32. Kelly, Creating a National Home, 142-44.

33. ISH case file 1248 (Alfred Renshaw, pension certificate \#944614), 11/12/ 1894, Iowa Veterans' Home, Marshalltown, Iowa. I am grateful to the administrators of the Iowa Soldiers' Home at Marshalltown for their invaluable assistance with this project.

34. ISH case file 11 (George Strabow, pension certificate \#569732), 12/28/1887. 
tober 1861 when he was paroled after capture, was readmitted an astounding nine times starting in January 1888. Neville was not even disabled in the line of duty: "After my discharge I was working on a hospital boat running from Memphis to Pittsburg," he reported on his ISH application. Approximately one week after mustering out, "I was caught in the machinery of the boat and lost my right arm." Neville exemplified the pattern of seasonal discharges common to both the ISH and the NHDVS. Outside the home, he somehow got by as a common laborer despite his infirmity until 1890, when he finally received a $\$ 12$ per month pension under the Dependent Pension Act. He died at the home in the spring of $1902 .^{35}$

WITH THIS MUCH MOVEMENT-and Neville, Tracy, and the rest represent a tiny fraction of the thousands of men who passed through the ISH between 1887 and 1910-it was crucial for ISH officers to maintain soldierly discipline on the grounds. Iowans expected to see their veterans cared for, but they demanded that old soldiers prove themselves worthy of largesse by comporting themselves as veterans. Thus they were closely regulated in appearance and manner. The inmates wore "the regular G.A.R. uniform," an inmate told the Lyon County Register in early 1888, "with G.A.R. buttons, blue flannel shirt and black hat with gold cord and tassel, and a change of underclothing." This particular veteran was happy with his lot-he called the ISH a true "home for the old broken down soldier not only in name, but in the fullest sense of the term"-but the uniform, with its attendant inspection, grated on many others. ${ }^{36}$

Nevertheless, it was not optional. Rule 14 mandated that "inmates shall appear at all times, in the uniform or dress established by the Board of Commissioners"; and Rule 15 specified that "at reveille the inmates shall rise, wash and dress themselves neatly; and when assembled for breakfast, before entering the dining room, the officer in charge of each detachment,

35. ISH case file 33 (Henry Tracy [no pension certificate]), 12/15/1887; ISH case file 48 (William Stone, pension certificate \#254544), 12/28/1887; ISH case file 53 (Noah H. Isenhower, pension certificate \#275779), 12/31/1887; ISH case file 67 (Patrick Neville, pension certificate \#534422), 1/10/1888.

36. Lyon County Register, 1/20/1888. 
shall inspect his men and report any neglect to the commandant." This "neglect" — which could be any failure of soldierly demeanor-could be punished by fatigues. In veteran parlance, that was being "put on dumps," and it could entail extra work on the inmate-run farm, a stint as a nurse in the ISH hospital, or even the kinds of pointless make-work punishment details they had suffered in the army some 30 years earlier-marching a fixed number of circuits or moving piles of firewood from one place to another. More serious infractions could be punished by a spell in the guardhouse or even expulsion. ${ }^{37}$

Movement was regimented in military fashion. Those who were physically able were liable to be assigned to work details (compensated, in 1890, at the rate of 30 cents per day; the freemarket rate was 44 cents per day). Those who were sick were obliged to wait until the morning's sick call before being allowed to report to the surgeon's office. Access to "the barns, stables, shops, kitchens, laundry, or detached buildings, without permission of the Commandant" was forbidden, and furloughs were required to leave the grounds. The day ended with a military-style tattoo from the bugler, at which point all residents were required to repair to their rooms and prepare for lights-out. ${ }^{38}$ Presumably the lights-out rule was loosened for meetings of the in-home GAR post organized in August 1888, but otherwise the veterans lived in the home much as they had in camp 40 years earlier-with the exception, of course, of the watchful eyes of curious civilians. ${ }^{39}$

IN SHORT, the officers and residents of the ISH were forever engaged in a complex negotiation between charity, discipline,

37. These and all subsequent ISH rules quoted can be found, unless otherwise noted, in the Visiting Committee Report, 1888, 7-10. On Union army discipline, see especially Steven J. Ramold, Baring the Iron Hand: Discipline in the Union Army (DeKalb, IL, 2010).

38. For compensation, see Visiting Committee Report, 1890, 5. Free-market wages based on the $\$ 13.29 /$ month average for farm labor with board in 1890; see Statistical Abstract of the United States, vol. 59 (Washington, DC, 1938), 602.

39. Iowa State Reporter (Waterloo), 8/2/1888. The organization of the GAR was patterned on the Union army. States were departments; individual chapters within a department were called posts. At its peak, the GAR had several hundred posts in Iowa. See Mindling, "GAR in Iowa Politics." 
and disability. In return for desperately needed asylum care, veterans who entered the ISH were expected to play the part of wounded warriors. The fact that they were not the conquering army of their youth, however-and were, in fact, rapidly passing into senescence-added an element of farce to the proceedings that the veterans deeply resented. The simplest explanation for the drinking problems that plagued all soldiers' homes, for instance, is that drinking was one of the few recreations available. The nineteenth century simply had no experience with the long-term care of non-deviant populations. Workhouses, insane asylums, prisons, orphanages, and even schools for the disabled were intended as temporary refuges for the rehabilitation of society's outcasts. ${ }^{40}$ The ISH and its sister institutions were, in effect, prototypical nursing homes, but it would take until the twentieth century for medicine to devote any serious attention to the elderly and their unique problems. Soldiers' homes thus were often little more than warehouses for chronically ill old veterans who were forced to play dress-up for their daily bread.

In some ways, the ISH was actually better than most state soldiers' homes-and even some branches of the NHDVS. The Iowa home, for instance, maintained a farm, a sewing room, a carpenter shop, a bakery, and a laundry, all staffed with inmate labor; veterans could earn a little pocket money and still feel like somewhat productive members of society. ${ }^{41}$ The Northwestern Branch of the NHDVS, by contrast, employed less than a third of its members; perhaps not coincidentally, its residents were plagued by a variety of maladies that seemed to be the result of simple despair. Elizabeth Corbett, whose father had been an officer there in the late 1800s, left a vivid description of

40. On poorhouses, see especially Katz, In the Shadow of the Poorhouse. For other institutions, see especially Benjamin Reiss, Theaters of Madness: Insane Asylums and Nineteenth-Century American Culture (Chicago, 2008). The classic studies remain Gerald N. Grob, Mental Institutions in America: Social Policy to 1875 (New York, 1972); and Gerald N. Grob, From Asylum to Community: Mental Health Policy in Modern America (Princeton, NJ, 1991). On prisons, see especially Randall G. Shelden, Controlling the Dangerous Classes: A History of Criminal Justice in America, 2nd ed. (Boston, 2008). For deaf schools, see especially Douglas C. Baynton, Forbidden Signs: American Culture and the Campaign against Sign Language (Chicago, 1996).

41. Commissioners Report, 1905, 36-37. 
the old soldiers whiling away their time. They "rarely bathed and frequently swore," historian James Marten summarizes, and "their offbeat hobbies" included "collecting burned matches, manufacturing and wearing counterfeit medals, 'curing' deadly diseases, and proposing to women visitors, inevitably claiming to have run away to become drummers in the Union army as little boys." ${ }^{42}$ With nothing to keep them occupied, veterans at Milwaukee's NHDVS slipped into torpor.

Age compounded the problem. Although it was better provided with pastimes than most, even the ISH could not arrest the ravages of time. Indeed, a large portion of the ISH's membership was aged and simply incapable of doing meaningful work from the day the institution opened its doors. "Many of the inmates are well advanced in years," Commandant Milo Smith wrote in 1889, "or are broken in health from exposures or wounds, and quite a large per cent of them require medical treatment and attention which cannot be given them without additional hospital facilities." Moreover, the designers of the home had not allowed for the age of the inmates in their plans, placing the kitchen in the basement. For the inmates who served as nurses for their fellows, the arrangement forced a climb "up a long flight of stairs by men that can with difficulty go up and down stairs without any load." So, too, presumably, with the farm, which had begun operation the previous year. Given that an inability "to earn a $1 / 4$ living at manual labor" was one of only two admission criteria, it stands to reason that the climb from the basement was a trial for just about any veteran sick enough to gain admission. ${ }^{43}$

PAST THE TURN of the twentieth century, the size, frequency, and complexity of geriatric problems increased. By 1905, Commandant C. C. Horton was pressing the legislature to consider tax increases to support a new hospital. "In view of the advancing age of our members," he wrote in his biennial report for that year, "more citizen help will doubtless be required in the near

42. See Marten, "Nomads in Blue," 279-86.

43. Commissioners Report, 1889, 4-5. The other criterion for admission was, of course, an honorable discharge from the Union army or navy. 
future." He reminded his superiors that "many new members are hospital patients from the start," and he reiterated the home's perennial request for additional funding. He also begged for appropriations to construct a separate library, as the present one was "altogether too small and will, at best, accommodate but about twenty-five members at a time." With fewer members physically able to work in the home's shops and farms, hospital beds and reading room space were fast becoming top priorities. Surgeon Duffield concurred-in his estimation, the year 1920 would find the home "crowded to overflowing," and he anticipated that the upcoming winter of 1905 would find the hospital "more crowded . . . than ever before." Although the ISH was chronically understaffed, by this time Duffield was provided with a superintendent of nurses, an assistant nursing superintendent, a hospital steward, a consulting surgeon, and an assistant surgeon. But it was still not enough. Between June 1904 and June 1905, 456 residents were treated in the hospital; another 1,008 were treated in their quarters; and medicines were issued to patients in their quarters an astounding 7,498 times. On average, 118 persons were in the hospital monthly during that year. ${ }^{44}$

With that level of illness, and few resources with which to profitably pass the time, it is little wonder that many residents of soldiers' homes turned to drink and other forms of misbehavior like the ones documented by Elizabeth Corbett. Moreover, evidence from the modern era suggests that even the most well-intentioned institutions soon impress a strict behavioral code on their members-in short, they become total institutions, to employ sociologist Erving Goffman's characterization of modern custodial facilities. In a total institution, residents' "every movement is controlled by the institution's staff." Soon "an entirely separate social world comes into existence within the institution, which defines the inmate's social status, his relationship to all others, his very identity as a person." In a total institution, personalities become flattened; with few avenues for the effective expression of the individual self, inmates can only resist depersonalization through small infractions. With their movements, gestures, and even attitudes closely monitored,

44. Commissioners Report, 1905, 8-10, 47-49. 
inmates of total institutions tend to "act out" in bizarre, irrational ways. Clearly the price of care was very high for Iowa's disabled veterans. ${ }^{45}$

TOTAL INSTITUTIONS affect the staff almost as much as they do the patients, though. The pressure of competing and often contradictory priorities pushed ISH officers into some odd behavior of their own. A case study is useful. When George W. Bettesworth, late of the 2nd Iowa Infantry, applied for admission in the spring of 1902, he was in his mid-sixties, about the average age of Union veterans at the time. Like most inmates, he was a casualty of disease rather than wounds. Generally "feeble," he was suffering from chronic diarrhea, hemorrhoids, and a latent case of malaria. Home Surgeon Duffield concluded that Bettesworth was "unable to earn a $1 / 4$ living at manual labor" and on that basis provisionally approved his admission. ${ }^{46}$

In one crucial respect, however, Bettesworth was far from typical. His mind was "agitated," he claimed on his application, and Duffield concurred. He pronounced Bettesworth "medically deranged" and added, "I am inclined to think he is not a fit subject for us. His place is in the asylum." ${ }^{47}$ Nonetheless, Duffield admitted Bettesworth into the home on May 27, 1902, and, except for a brief stay in the Minnesota Soldiers' Home in Hennepin County, just outside of Minneapolis, he would remain at the ISH until his death in $1917 .{ }^{48}$ Moreover, the mental agitation he displayed at his admission physical would, by 1905, blossom into a set of obsessive delusions about the mystical connection between various biblical figures, electric current, the geography of Iowa, the cabbala, and a number of other widely divergent

45. See Samuel E. Wallace, "On the Totality of Institutions," in Total Institutions, ed. Samuel E. Wallace (New Brunswick, NJ, 1971), quotes on pp. 1-2. See also Erving Goffman, Asylums: Essays on the Social Situation of Mental Patients and Other Inmates, Aldine Library Edition (Chicago, 1962).

46. Iowa Soldiers' Home registry \#2446, filed May 28, 1902, by George W. Bettesworth (hereafter referred to as ISH file); National Archives pension file \#C-2531,261 (George W. Bettesworth) (hereafter cited as NA pension file).

47. ISH file; Home Surgeon's Certificate (5/27/1902).

48. ISH file; NA pension file; Minnesota Soldiers' Home file for George Bettesworth (1916), Minneapolis Veterans Home, Minneapolis, Minnesota. 
subjects. As evidenced by a series of manuscripts held at the Bakken Museum in St. Paul, Minnesota, and the State Historical Society in Iowa City, Bettesworth pursued his delusions with the active support of the ISH staff. His writings are dense with allusions to current events and contain many clippings of current newspapers that could only be obtained through the ISH library; most surprisingly, the manuscripts are printed with the ISH imprint on the front matter. ${ }^{49}$

Duffield's decision to not only admit but also to abet Bettesworth only makes sense within the context of the negotiations discussed above. The ISH was not obligated to retain the mentally ill. Indeed, within a few months of its opening, the state legislature's visiting committee asserted the right to refuse admission to mentally impaired old soldiers. "Men requiring continual care by reason of insanity or imbecility," the committee decreed in its 1888 report to the General Assembly, "will not be retained at the Home, because no provisions have been made to take care of such persons." The commandant was given authority to refuse or transfer such cases. ${ }^{50}$ However, complaints about the "harmless but incurably insane" who were "daily" swelling the ranks of the ISH were a regular feature of Surgeon Duffield's reports. ${ }^{51}$

Financial considerations made "harmless" lunatics a valuable source of support for the ISH. The Iowa GOP made much political hay out of the initial $\$ 75,000$ appropriation for the ISH in 1886, but in reality the institution was-and would remainpathetically underfunded. In 1890, by contrast, the state offered the Soldiers' Monument Commission $\$ 100,000$ to fund a memorial to Iowa's Civil War veterans outside the Capitol. Urging the state to "build nobly or not at all," the monument commission

49. The Bakken Museum (www.thebakken.org), founded by inventor and Medtronics cofounder Earl Bakken, bills itself as "the world's only library and museum collection devoted primarily to medical electricity." The Bakken library collection contains separate prints of five different Bettesworth manuscripts, all dealing with the mystical aspects of electricity (among many other farranging topics). The State Historical Society of Iowa contains a bound copy of all five works in its Iowa City library. On Bettesworth's insanity, see medical reports in NA pension file and ISH file.

50. Visiting Committee Report, 1888, 7.

51. See especially Commissioners Report, 1902, 19. Duffield mentioned the "harmless but incurably insane" often in his reports. 
haughtily declared that "twice that sum at least will be required to erect a work that will in any full degree come up to the mark of this people's patriotic feeling" and suggested raising $\$ 33,000$ yearly until that goal was met. ${ }^{52}$ In 1890 the entire appropriation for desperately needed new hospital facilities at the ISH was $\$ 25,000$, and it was making do with a maintenance budget of a mere 10 dollars per man per month. This worked out to a mere 13 cents per man per day spent on food, which was actually down from the 14.8 cents in the home's first full year of operation. (Increased production on the inmate-worked farm, up to $\$ 899.79$ from $\$ 481.23$, was expected to counter the shortfall). ${ }^{53}$

Thus the retention of "harmless but incurably insane" old soldiers became a budgetary necessity for the ISH. Starting in 1889, the Sundry Civil Act granted a $\$ 100$ annual federal subsidy for each man housed in a state soldiers' home. Each man retained by the ISH would thus nearly double its per capita maintenance budget. Moreover, as with all other state and federal homes, inmates at the ISH were required to surrender the bulk of their pensions to the home's support fund (though the Iowa home was "the most generous" of all, Commandant Horton bragged in 1900, in allowing its residents to keep \$6 per man, an amount "far exceeding" that of other homes). ${ }^{54}$ With the Dependent Pension Act of 1890 making "all survivors of the war whose conditions of health are not practically perfect" eligible for federal assistance, the ISH was increasingly assumed to be financially self-supporting. Add in the home's obligation to pay for the upkeep of any men it remanded to the insane asylum-there were five of them in 1890 at a cost of \$14 per man per month-and the retention of harmless lunatics seemed the only sensible course. ${ }^{55}$

52. Commissioners Report, 1888, 4; Iowa Soldiers' Monument Commission, First Report of the Iowa Soldiers' Monument Commission, to the Twenty-Third General Assembly (Des Moines, 1890), 4-5.

53. Visiting Committee Report, 1890, 4-6.

54. See, for example, Commissioners Report, 1900. Commandant Horton routinely bragged of the ISH's generosity in this regard.

55. McConnell, Glorious Contentment, 153; Commissioners Report, 1889, 14; Commissioners Report, 1905, 35; Visiting Committee Report, 1890, 4. 
The numbers provided by ISH officers and the legislature's visiting committees bear this out. The federal government had provided an additional $\$ 16,865$ in aid to the ISH through the end of 1888, but with those meager funds the ISH was expected to care for 350 veterans, including "nearly thirty cases that are practically bedridden of old chronic cases who entered the home in a helpless condition." Moreover, the legislature's visiting committee reported, "This class of cases would largely increase if the hospital accommodations of the Home would admit of it." As it was, the ISH had already "been obliged to use two other wards for hospital patients, neither of which [had] the conveniences necessary for the comfort of the patients." ${ }^{56}$

Lack of hospital funds would be a constant refrain in the home's first two decades of operation. By the turn of the century, the ISH was caring for over 600 men, with 77 more or less permanently in the hospital, with nothing like a proportional rise in its operating budget. The home's hospital was thus "severely taxed" during the "early fall, winter, and spring," Duffield wrote in 1902, which led to "many needing its care [being] turned away." The ISH simply could not afford to bypass any possible source of revenue-by 1900 it was retaining over $\$ 5,000$ per year in federal money from more than 500 pensioners among its residents. ${ }^{57}$

Still, by 1902, when George Bettesworth entered the home, Duffield had to provide care for more than 600 men for a mere $\$ 100$ per month. By 1905 the total population of the ISH would surge to just under 800 , with 369 of them age 68 or older. ${ }^{58}$ Thus Bettesworth-who, "medically deranged" or no, kept a keen eye on his federal benefits-would have been a good risk for Duffield if Bettesworth could keep his illness in check.

Moreover, Duffield was undoubtedly constrained by political pressure. Benjamin Harrison's successful presidential campaign of 1888 accused Democrat Grover Cleveland of "weighing the claims of old soldiers with apothecary's scales." The Republicans ousted Cleveland again in 1896 on the strength of the

56. Commissioners Report, 1889, 15; Visiting Committee Report, 1890, 5-6.

57. Commissioners Report, 1902, 17-18.

58. Commissioners Report, 1906, 24, 26; Commissioners Report, 1902, 10, 11. 
soldier vote. After a brief lull in 1890, the GAR-dominated GOP would continue its dominance of Iowa's statehouse until the 1930s. ${ }^{59}$ Sending an old soldier to a state insane asylum under such conditions would be politically unwise, but especially so for Dr. Hamilton P. Duffield.

Like all officers of the ISH, Duffield was a Civil War veteran, but he owed his place almost entirely to the politicking of the home's second commandant, John Keatley. Col. Keatley had explicitly lobbied the state legislature to remove the home's current surgeon, Dr. G. W. Harris, on the grounds that Harris was not "a veteran of the late war." Duffield, who had mustered out as a corporal in 1864, was installed as home surgeon with the rank of major in 1894-which year was, probably not coincidentally, the end of the tenure of Horace Boies, Iowa's only Democratic governor between the end of the Civil War and the New Deal. ${ }^{60}$ Duffield was no doubt a man who knew how to tread carefully.

Provided George Bettesworth could maintain the outward demeanor of a soldier, then, there were no disadvantages, and a great many advantages, to maintaining him at the home. From all remaining evidence, Bettesworth was obedient and tractable so long as he was free to pursue his peculiar hobby. Given the overcrowding of the hospital and the drunken antics of many members, it is likely that Bettesworth would hardly have appeared on the institution's radar at all. To Duffield, he was just one more feeble old man among many. To the visitors who flocked to the ISH to see the old soldiers on display, Bettesworth was just another aged veteran in a GAR uniform. So long as he could wear the uniform and march to the bugle, he was of little official interest to anybody.

By 1910, Duffield was urging the construction of "suitable quarters, an exercising yard and about four extra guards or orderlies" to supervise the increasing number of harmless but

59. On Harrison, see McConnell, Glorious Contentment, 152; see also Mary Rulkotter Dearing, Veterans in Politics: The Story of the G.A.R (Baton Rouge, LA, 1952). On the election of 1896, see especially Patrick J. Kelly, "The Election of 1896 and the Restructuring of Civil War Memory," Civil War History 49 (2003), 254-80.

60. Commissioners Report, 1892. On Iowa political history of the era, see Kenneth Roland Walker, A History of the Middle West: From the Beginning to 1970 (Little Rock, AR, 1972); and Leland L. Sage, A History of Iowa (Ames, 1974). 
senile old soldiers. With such facilities, "there would be no necessity for sending them to the hospital for insane." Since "soldiers' homes, national and state, were built largely from sentiment," the new facilities would allow the public to see that even the feeblest were being cared for thoroughly and humanely. ${ }^{61}$

"THE FACT REMAINS," as historian Patrick Kelly wrote of the NHDVS, "that Union veterans received care in an asylum, albeit a relatively modern, comfortable, and humane one." In a culture that did not tolerate large-scale institutional charity, the only way to maintain what was in effect a nursing home at taxpayer expense was to constantly remind the public of the inmates' sacrifices for the Union. To do that, soldiers' homes like the ISH became tourist destinations, and the old soldiers were required to display themselves as wounded warriors-that is, they would perform their disability by marching in uniform and living under military discipline. Rosemarie Garland Thomson, Lennard Davis, and other historians of the subject argue that disability is essentially "performative"; that is, "disability" exists only in relation to a social construct called "normality," and both are mutually interdependent. For those men who did not bear the "honorable scars" of combat, the only way to show that they were not drunks, bums, frauds, or loafers was through the uniform. Although they may have resented being spectacles "like monkeys at the Zoo," their performance entitled them to what was at that time the most extensive and liberal public assistance scheme in the world. ${ }^{62}$

61. Commissioners Report, 1910, 41.

62. Kelly, Building a National Home, 7. On disability, see especially Rosemarie Garland Thomson, Extraordinary Bodies: Figuring Physical Disability in American Culture and Literature (New York, 1997); Lennard J. Davis, Enforcing Normalcy: Disability, Deafness, and the Body (New York, 1995). See also Paul K. Longmore and Lauri Umansky, The New Disability History: American Perspectives (New York, 2001), and the many excellent essays in The Disability Studies Reader, ed. Lennard J. Davis (New York, 1997). 